\title{
Social Workers in Pediatric Intensive Care Units: A Physician Perspective
}

\section{Çocuk Yoğun Bakım Ünitesinde Sosyal Hizmet Uzmanları: Bir Hekim Bakışıyla}

\author{
Gulhan ATAKUL ${ }^{1}$, Kazim ASLAN ${ }^{2}$, Ozge DEMIRCAN TULACI ${ }^{3}$, Perihan OZHAN ${ }^{1}$, Atika CAGLAR ${ }^{1}$
}

${ }^{1}$ Pediatric Intensivist, Balıkesir Ataturk City Hospital, Balıkesir, Turkey

${ }^{2}$ Social Services, Balıkesir Ataturk City Hospital, Balıkesir, Turkey

${ }^{3}$ Child Psychiatry Department, Balıkesir Ataturk City Hospital, Balıkesir, Turkey

\begin{abstract}
Objective: The role of social workers, who are beginning to be integrated into the entire health system, is now becoming more and more understood. In our study, we aimed to discuss the duties of social workers at PICU, the results of their work in harmony with the physicians, and their importance for the intensive care team.

Material and Methods: Sixtysix children aged between 1 month and 18 years old who were asked for social service consultation between January 2019 and December 2020 at our hospital's PICU were included in the study. The age, diagnosis, sex, marital status (married-divorced), number of days of hospitalization, number of recurrent hospitalization, reason and result of consultation, necessity of psychiatric consultation and frequency of follow-up were retrospectively examined and recorded through the hospital information system. The collected data were analyzed by means of SPSS (version 22.0, SPSS Inc. Chicago, IL, USA).

Results: The median age (months) (min-max) was found to be 172, 50 (6-209), and the median (min-max) duration of hospitalization (days) was found to be $2(1-76)$. Family neglect was found to be the most common cause of social work indications (77.3\%; n: 51). The number of patients who were given social counseling and referred to a psychiatrist was 25 (37.9\%). Family neglect and abuse were detected in 5 (7.6\%) patients. Apart from these, it was observed that problems such as drug supply, financial support, ID application, home device supply assistance, care center approvals and child custody were solved in each 1 (1.5\%) patient.

Conclusion: The inclusion of social workers in the children's intensive care unit teams can also prevent many social problems that can be neglected otherwise. Physicians are more focused on patient treatment, so we believe that it will be beneficial to question the family and social status of patients together with a social service unit and specialists integrated into children's intensive care units.
\end{abstract}

Key Words: Child psychiatry, Child abuse, Pediatric intensive care unit, Social worker

\section{ÖZ}

Amaç: Tüm sağlık sistemine entegre olmaya başlayan sosyal hizmet uzmanlarının rolü giderek daha iyi anlaşılmaktadır. Çalışmamızda, çocuk yoğun bakım ünitesinde (ÇYBÜ), sosyal hizmet uzmanlarının ÇYBÜ'deki görevlerini, hekim ile uyumlu çalışmasının sonuçlarını ve yoğun bakım ekibi için önemini tartışmayı amaçladık.

Gereç ve Yöntemler: Hastanemiz ÇYBÜ'de 2019 Ocak-2020 Aralık tarihleri arasında 1ay-18 yaş arası çocuk hastalardan, sosyal hizmet konsültasyonu istenmiş 66 hasta çalışmaya dahil edildi. Hastaların yaş, tanı, cinsiyet, aile

(10)

0000-0002-3832-9691: ATAKUL G 0000-0003-3112-2871: ASLAN K 0000-0002-7174-2154: DEMIRCAN TULACI 0000-0002-1098-5056: OZHAN P 0000-0003-1721-354X: CAGLAR A

\begin{abstract}
Conflict of Interest / Çıkar Çatışması: On behalf of all authors, the corresponding author states that there is no conflict of interest. Ethics Committee Approval / Etik Kurul Onayr: This study was conducted in accordance with the Helsinki Declaration Principles. The ethics committee decision of our study was approved by the Ballkesir University ethics committee with the number E-94025189-050.03-15740 on 18/02/2021.

Contribution of the Authors / Yazarların katkısı: ATAKUL G: Constructing the hypothesis or idea of research and/or article, Planning methodology to reach the Conclusions, Taking responsibility in logical interpretation and conclusion of the results, Taking responsibility in the writing of the whole or important parts of the study. ASLAN K: Planning methodology to reach the Conclusions, Organizing, supervising the course of progress and taking the responsibility of the research/ study, Taking responsibility in the writing of the whole or important parts of the study, Reviewing the article before submission scientifically besides spelling and grammar. DEMIRCAN TULACI O: Organizing, supervising the course of progress and taking the responsibility of the research/study, Taking responsibility in necessary literature review for the study, Taking responsibility in the writing of the whole or important parts of the study. OZHAN P: Taking responsibility in patient follow-up, collection of relevant biological materials, data management and reporting, execution of the experiments. CAGLAR A: Taking responsibility in logical interpretation and conclusion of the results, Taking responsibility in necessary literature review for the study, Reviewing the article before submission scientifically besides spelling and grammar.

How to cite / Atıf yazım şekli : Atakul G, Aslan K, Demircan Tulacı O, Ozhan P and Caglar A. Social Workers in Pediatric Intensive Care Units: A Physician Perspective. Turkish J Pediatr Dis 2022;16:307-312.
\end{abstract}

Received / Geliş tarihi : :08.05.2021 Accepted / Kabul tarihi : 28.10.2021 Online published 11.01 .2022 Elektronik yayın tarihi 
durumu (evli-boșanmış), yatıș gün sayısı, tekrarlayan yatıș sayısı, konsültasyon nedeni ve sonucu, psikiyatri konsültasyonu gerekliliği ve takip sıklığı retrospektif olarak hastane bilgi sistemi üzerinden incelenerek kaydedildi. Toplanan veriler SPSS (version 22.0, SPSS Inc. Chicago, IL, USA) ile analiz edildi.

Bulgular: Hastaların yașları (ay) median (min-max); 172.50 (6-209) ve median (min-max) yatıș süreleri (gün); 2 (1-76) olarak bulundu. Sosyal hizmet endikasyonları arasında en sık nedenin aile ihmali intimalinin değerlendirmesi, suicid girişimleri ile psikiyatrik sorun tespiti açısından değerlendirilmesi (\%77.3; n:51) olduğu tespit edildi. Sosyal danışmanlık verilen ve psikiyatri uzmanına yönlendirilen hasta sayısı 25 (\%37.9)'du. 5 (\%7.6) hastada aile inmali ve istismar tespit edildi. Bunlar dışında 1 (\%1.5)'er hastada, ilaç temini, maddi destek, kimlik başvurusu, ev tipi cihaz temini yardımı, bakım merkezi onamları alınması ve çocuğun vasi sorunu çözümü gibi sorunların çözüldüğü görüldü.

Sonuç: Sosyal hizmet uzmanlarının çocuk yoğun bakım ünitesi ekibine dahil edilmesi, gözden kaçabilecek birçok sosyal problemin de önüne geçmeyi sağlayabilir. Hekimlerin hasta tedavilerine daha çok odaklanması nedeniyle, çocuk yoğun bakım ünitelerine entegre olmuş bir sosyal hizmet birimi ve uzmanları ile beraber hastaların aile ve sosyal durumlarının sorgulanmasının fayda sağlayacağını düşünmekteyiz.

Anahtar Sözcükler: Çocuk psikiyatrisi, Çocuk istismarı, Çocuk yoğun bakım ünitesi, Sosyal hizmet uzmanı

\section{INTRODUCTION}

Social workers, are specialists who provide services such as organizing the relations of the patient with their family and environment, resolving personal and family problems after leaving the hospital, and developing skills to cope with their problems with their professional knowledge, skills and discipline in addition to the economic, social, psychological, educational, supportive and developing services to be carried out in order to ensure effective use of medical treatment for outpatient or inpatient examinations (1). Social workers assess, include, intervene, coordinate and advocate on behalf of the most vulnerable populations, while addressing non-medical factors and social needs that affect health with a focus on equality. According to the ethical rules of the National Association of Social Workers (NASW), the primary mission of the social workers is to pay special attention to the needs and empowerment of people who are vulnerable, oppressed and living in poverty, enhance human well-being and help meet the basic human needs of all people. A historical and distinctive feature of social work is that the profession focuses on individual well-being and the well-being of society in a social context. The basis of social work is to pay attention to the environmental forces that create, contribute to and address problems in life (2).

Today, social workers are employed in many hospitals in our country. According to Article 35 of the Inpatient Treatment Institutions Regulation: "1 social worker is employed for every 100 beds". Accordingly, Balıkesir Atatürk city hospital has the right to employ 10 social workers according to the health personnel distribution chart of the Ministry of Health (3). There are approximately 650,000 social workers in the United States, more than half of whom work in healthcare settings (4). The data in Turkey were presented at a symposium held in Manisa in 2015 and these data show that a total of 1007 social workers work actively, 918 in institutions affiliated to the Ministry of Health, 75 in university hospitals, 14 in private hospitals in the field of medical social services, and most social workers are employed in institutions affiliated to the Ministry of Health (5). It can be predicted that this number may have increased with additional appointments since 2015, but this number has not yet been presented in any article.
In Turkey, there is no study reporting the need for a social worker in pediatric intensive care units (PICU) and its effects on pediatric intensive care. In our study, we wanted to show the importance and results of the roles of social workers in intensive care units and their harmonious work with physicians by examining the consultation data referred from the pediatric intensive care units to the social service units.

\section{MATERIALS and METHODS}

Our pediatric intensive care unit in Balıkesir Atatürk city hospital has 19 beds and serves patients requiring level 2 and 3 intensive care with different diagnoses. There are currently 8 social workers working actively within our hospital and social workers have been actively assigned in certain departments: 2 are in the child follow-up center, 1 in the community mental health center, 1 in the home health unit, 1 in the palliative care center, 1 in the addiction counseling unit and the other 2 carry out the works and operations in the medical social service unit of the hospital. 66 children aged between 1 month and 18 years old who were asked for social service consultation between January 2019 and December 2020 at our hospital's PICU were included in the study. The age, diagnosis, sex, marital status (married-divorced), number of days of hospitalization, number of recurrent hospitalization, reason and result of consultation, necessity of psychiatric consultation and frequency of followup were retrospectively examined and recorded through the hospital information system. The collected data were analyzed by means of SPSS (version 22.0, SPSS Inc. Chicago, IL, USA). The ethics committee decision of our study was approved by the Balıkesir University ethics committee with the number E-94025189-050.03-15740 on 18/02/2021.

\section{RESULTS}

In our study, the data of a total of 66 patients were examined. The median age (months) (min-max) was found to be 172, 50 (6-209), and the median (min-max) duration of hospitalization (days) was found to be $2(1-76) .46$ (69.7) of the patients were 
Table I: Distribution of diagnoses by age groups.

\begin{tabular}{|c|c|c|c|c|}
\hline \multirow[b]{2}{*}{ Diagnosis $\mathrm{n}$} & \multicolumn{3}{|c|}{ Age Group (ay) } & \multirow[b]{2}{*}{$\begin{array}{c}\text { Total } \\
\mathbf{n}\end{array}$} \\
\hline & $\begin{array}{c}\text { 0-72 month } \\
n(\%)\end{array}$ & $\begin{array}{c}\text { 72-144 month } \\
\mathrm{n}(\%)\end{array}$ & $\begin{array}{c}\text { 144-208 month } \\
\text { n (\%) }\end{array}$ & \\
\hline Suicide / intoxication & 0 & $2(5.1)$ & 37 (94.9) & 39 \\
\hline Accidental intoxication & $8(100)$ & 0 & 0 & 8 \\
\hline Neurological diseases & $8(88.9)$ & 0 & $1(11.1)$ & 9 \\
\hline Sepsis & $1(100)$ & 0 & 0 & 1 \\
\hline Diabetic Ketoacidosis & 0 & 0 & $2(100)$ & 2 \\
\hline Drowning & 0 & $1(100)$ & 0 & 1 \\
\hline Falling from high & $2(100)$ & 0 & 0 & 2 \\
\hline Respiratory diseases & $1(50)$ & 0 & $1(50)$ & 1 \\
\hline Substance use & $1(50)$ & 0 & $1(50)$ & 1 \\
\hline Total (n) & 21 & 3 & 42 & 66 \\
\hline
\end{tabular}

Table II: Consultation reasons for patients who are asked to be evaluated by social workers.

\begin{tabular}{l|c}
\hline Consultation reasons & $\mathbf{n}(\%)$ \\
\hline $\begin{array}{l}\text { Detection of negligence or psychiatric } \\
\text { problems }\end{array}$ & $51(77.3)$ \\
\hline Trouble reaching the family & $5(7.6)$ \\
\hline Providing refugee assistance & $1(1.5)$ \\
\hline Assessment of care center requirement & $2(3)$ \\
\hline Assessment of need for social counseling & $4(6.1)$ \\
and socioeconomic support & $1(1.5)$ \\
Home appliance supply assistance & $2(3)$ \\
\hline Home transport assistance & $66(100)$ \\
\hline Total
\end{tabular}

female and 20 (30.3) were male. 42 (63.6) of the patients who requested consultation were followed up in Level $2 \mathrm{PICU}$ and 24 (36.4) in Level 3 PICU. Considering their attendance to school, it was observed that 21 (31.8\%) patients were not at school age, 40 (60.6\%) patients were attending school, and 5 (7.6\%) patients dropped out of school. When the marital status of the patients' families was questioned, it was learned that 21 (31.8\%) families were divorced and 45 (68.2\%) families were still married. 61 (92.4\%) of our patients who needed social service consultation were Turkish citizens, 2 (3\%) were Syrian citizens, $1(1.5 \%)$ was Iranian citizen and 2 (3\%) were Afghan citizens. 19 of the patients (28.8\%) had recurrent PICU admission. The diagnoses of the patients evaluated by social workers according to their age groups are given in Table I. The reasons for the consultation of the patients who are asked to be evaluated by social workers are given in Table II. The consultation results of patients who are asked to be evaluated by social workers are shown in Table III.

It was seen that $39(59.1 \%)$ of the 66 patients in our study were evaluated by a child psychiatrist, and 13 (33.3\%) of them required psychologist follow-up. When the patients were
Table III: Consultation results for patients who are asked to be evaluated by social workers.

\begin{tabular}{|l|c|}
\hline Consultation results & $\mathbf{n}(\%)$ \\
\hline Social notification + referral to psychiatrist & $5(7.6)$ \\
\hline Social reporting and prosecution reporting & $2(3)$ \\
\hline Clothing and companion assistance & $1(1.5)$ \\
\hline Providing access to the family & $4(6.1)$ \\
\hline Obtaining consent and permissions for the care center & $1(1.5)$ \\
\hline Making an official application to initiate a social review & $4(6.1)$ \\
\hline Referral to social counseling and psychiatry specialist & $25(37.9)$ \\
\hline Detection of abuse or family neglect & $7(10.6)$ \\
\hline Social counseling service only & $4(6.1)$ \\
\hline Resolving the custody problem & $1(1.5)$ \\
\hline Ensuring the transfer of the patient and his family & $2(3)$ \\
\hline home & $5(7.6)$ \\
\hline Detection of abuse / family neglect & $1(1.5)$ \\
\hline Helping with identity application & $1(1.5)$ \\
\hline Socio-economic support assistance & $1(1.5)$ \\
\hline Home appliance supply assistance & $1(1.5)$ \\
\hline Supplying of quarantine document & $1(1.5)$ \\
\hline Medication assistance & 25 \\
\hline
\end{tabular}

examined in terms of their regular visits to child psychiatry specialist, it was found that $15(38 \%)$ of 39 patients continued their visits regularly. It was observed that $22(56 \%)$ of the patients who were evaluated by child psychiatry started treatment and 1 $(0.2 \%)$ patient was admitted to the child psychiatry service. The diagnoses of the patients evaluated by the child psychiatrist are given in table IV.

After the study data were collected, the social service department consultations requested for the neonatal unit were 
Table IV: Frequency of diagnoses by child psychiatry.

\begin{tabular}{l|c}
\hline Psychiatric Diagnoses & n (\%) \\
\hline Behavioral Disorder & $10(33.3)$ \\
\hline Depression & $12(40)$ \\
\hline Adaptation disorder & $3(10)$ \\
\hline Anxiety disorder & $4(13.3)$ \\
\hline Substance Use Disorder & $1(3.3)$ \\
Total & $30(100)$ \\
\hline
\end{tabular}

also questioned. There were 10 patients in a year, and it was learned that in 9 of them the family rejected the baby and the social status of 1 family was asked to be examined. The data of these patients were not included in the patients included in the study.

\section{DISCUSSION}

Understanding the professional collaboration between health and social workers is crucial as it is a vital part of achieving better patient outcomes, improving patient satisfaction, reducing hospital stays, reducing costs and contributing to fewer and shorter delays in delivery of care $(6,7)$. In addition to managing the medical treatments applied in intensive care units, palliative care centers, and health centers where oncology patients are monitored, it is possible to make assessments of the patient's non-medical needs and psychosocial status with team solidarity $(8,9)$. In the studies conducted, the need for social workers to participate in professional teams in the health sector and palliative care is also strongly discussed (10).

Nowadays, the number of intensive care units providing care and treatment of critical patients in the pediatric age group is also increasing. Therefore, the social needs of sick children increase in parallel. The social service unit, which has an increasing role in intensive care units, can solve patient problems in many issues and support the clinical team. In our study, we found that the pediatric intensive care physicians played an important role in achieving a clear result as patient and family oriented with a multidisciplinary approach, including social workers and, where necessary, child psychiatry specialists.

Although it seems that various indications lead to the need for social worker consultation, it is noticeable that the most common indications are suicide attempts and diagnoses of drug poisoning at a young age in order to ensure the detection of problems caused by a family or individual (patient) himself/ herself. From this point of view, it is important to ensure the detection of the situation of family neglect. Because physicians give priority to treatment, deepening the medical history should be considered as the contribution of the social worker. In terms of identifying and reporting child neglect and abuse cases of patients in PICU, social workers manage the process and take responsibility for reporting the crime. These reports are of great importance in combating child neglect and abuse, and also ease the workload of intensive care personnel at this point. In addition, patients are consulted with child psychiatry doctors and monitored. Interviews with the family about whether patients had repeated suicide attempts and whether they were undergoing psychiatric follow-up were one of the important contributions of social workers. In some studies conducted in our country, cases of childhood poisoning were examined and it was reported that family education and adolescent or family structures that are considered risky should be examined (11, 12).

The presence of refugee patients in our country leads to the need for more social support. In our study, social workers engaged in communication, information and financial support with the families of refugee patients. In addition, in terms of providing a companion before patient discharge, the determination of the parent who can take care of the child was also performed by the social worker. Their assistance to the family in applying for identification of patients, in case of necessity, accelerates the treatment and follow-up process from the point of view of the patient and the hospital. These aids contributed to the prevention of prolonged hospitalization and the efficient use of beds. But since our study is not specific to this topic, and our provable data is not studied statistically, it remains only at the level of opinion. After that, prospective studies can investigate the effect of social support on hospitalization periods of pediatric patients in pediatric services and PICUs.

Turkey has a heterogeneous structure in a socio-economic and cultural sense. In families with low socioeconomic levels, it is necessary to communicate with charities in order to provide some special needs for the sick child while in hospital. An important issue that we want to draw attention to in our study is that in terms of this economic support, social workers communicate with the necessary institutions for solving problems. Providing patients with access to their homes after discharge and providing medicines that families cannot provide are other important issues that the social workers solve.

When our patients in need of a social worker were divided into age groups, the vast majority were patients over 12 years of age, and this was followed by children between 0-6 years of age. We believe that this frequency increases due to periodspecific difficulties such as accelerating cognitive development during adolescence, increasing emotion intensity and impulsive behavior, choosing a profession, building relationships with the opposite sex. The younger age group is an age group open to neglect, which requires more attention for care and is difficult to follow from the point of view of the family. A study published in our country in 2012, in which 33 years of experience with drug intoxication in children was transferred, reported that two 
different peaks were observed in drug intoxication in similar age groups, in boys aged 1-5 and in girls aged 13-16 (13). It can be considered that the requirement for a social worker is parallel to the increase in similar age groups due to similar indications.

One of the most important consultant units referred to as a result of social worker and physician evaluation is child psychiatry specialists. As a result of the psychiatric evaluations of the patients evaluated by psychiatry, the most common psychiatric diagnosis was major depressive disorder (40\%; n =12). Depressive disorder is followed by behavioral disorder (33.3\%; $n=10)$, adaptation disorder $(10 \% ; n=3)$, anxiety disorders (13.3\%; $n=4)$ and substance use disorder. Studies conducted in 2013 and 2019 reported that child psychiatry consultations were most frequently requested due to suicide attempt and depressive symptoms $(15,16)$. In our study, it was determined that 15 (38\%) of the patients continued their visits regularly. In the studies conducted in Turkey, the rates of regular psychiatric treatment were found between 34\% and $70.2 \%$ $(14,16-18)$. When compared with these studies, the follow-up rate of our patients can be considered as low. This may be due to the difficulty in accessing the child psychiatrist and / or the low awareness of families about seeking psychiatric treatment. The reason is that our social workers serve different units, including adults, and do not work specifically for the pediatric intensive care unit. In order to prevent re-hospitalization of the patients who are evaluated in the pediatric intensive care unit and to continue their psychiatric visits regularly, we think that it will be beneficial to follow up regularly by a single social service specialist in charge of pediatric intensive care, and to ensure that families and children are followed up periodically. If we look at it from a different perspective, our study also covers the approximately 10-month period of the COVID-19 pandemic. Families and children may not be able to provide regular visits due to reasons such as the intensity of the pandemic in hospitals, changes in the appointment system and the possibility of infection.

Social workers have taken their place among the professions whose importance in the field of health has increased with the increasing importance of the psycho-social dimension of health. But despite the rapid expansion of the scope of services provided in the field of medical social work in Turkey, it is still believed that there are differences between hospitals and provinces in terms of professional staff and practices vary according to people, institutions and provinces. At this point, as well as the lack of regulations of the medical social service unit, the lack of staff and lack of in-service training cause variability in the quality of the service. Many healthcare professionals still do not have enough information about what kind of services the social worker provides. Generally, awareness can develop after a social worker solves a problem that a patient cannot solve about his / her psycho-social situation.
The inclusion of social workers in the children's intensive care unit teams can also prevent many social problems that can be neglected otherwise. Physicians are more focused on patient treatment, so we believe that it will be beneficial to question the family and social status of patients together with a social service unit and specialists integrated into children's intensive care units. Today, physicians and nurses working in pediatric intensive care units frequently take these responsibilities and try to question the family status of their patients, but these may be insufficient.

This study only includes one-year data of one hospital. This issue can be considered as a limitation of our study. As physicians, we estimate that there are many social problems in PICUs throughout Turkey and we believe that this issue should be investigated with multi-center studies. We think that healthcare providers must work in coordination with social workers to solve problems other than medical treatment, and this will increase the quality and effectiveness of service. For this reason, as pediatricians and social workers, we think that in a world where social and family social problems are increasing, there should be a social worker working actively in pediatric intensive care units.

\section{REFERENCES}

1. Saxe Zerden L MSW, PhD, Lombardi BM MSW, PhD, Jones A MSW, PhD. Social workers in integrated health care: Improving care throughout the life course. Soc Work Health Care 2019;58:142-9.

2. Workers, N. A. NASW Code of Ethics (Guide to the Everyday Professional Conduct of Social Workers). Washington, DC: NAS, 2017.

3. Republic of Turkey Ministry of Health Regulation of inpatient treatment institutions. Accessed October 20, 2016. Available from: https://www.mevzuat.gov.tr/ mevzuat?MevzuatNo=85319\&MevzuatTur=3\&MevzuatTertip $=5$

4. Bureau of Labor Statistics, Occupational outlook handbook: social workers. Accessed April 22, 2017. Available from: http://www.bls. gov/ooh/community-and-social-service/social-workers.htm.

5. S. Bekiroglu. Employment of social workers in the field of medical social work in Turkey. 50th Anniversary of Social Work Practice in Turkey: Promotion of Human Values and Dignity Social Work Symposium 26-28 November 2015; Manisa, Turkey 2016;341-51.

6. Sexton J, Thomas E, Helmreich R. Error, stress, and teamwork in medicine and aviation: cross sectional surveys. BMJ 2000;320:745-9.

7. Rafferty A, Ball J, Aiken L. Are teamwork and professional autonomy compatible, and do they result in improved hospital care? Qual Health Care 2001;10(Suppl II):ii32-7.

8. Ostadhashemi L, Arshi M, Khalvati M, et al. Social Workers in Pediatric Oncology: A Qualitative Study in Iranian Context. Asian Pac J Cancer Prev 2019;20:1871-7.

9. Thiel M, Mattison D, Goudie E, Licata S, Brewster J, Montagnini M. Social Work Training in Palliative Care: Addressing the Gap. Am J Hosp Palliat Care 2021;38:893-8. 
10. Vorobtsova ES, Martynenko AV, Ovchinnikova SV. The opinion of physicians about activities of professional social workers in organizations rendering palliative medical care. Probl Sotsialnoi Gig Zdravookhranenniiai Istor Med 2020;28:270-4.

11. Keskin M, Sarı E, Şenel S. Evaluation of cases admitted to a tertiary center with intoxication. Turk J Clin Lab 2018;9:81-6.

12. Ceylan G, Keskin M, Sandal Ö, Tunç G, Tuygun N, Yılmaz G. Analysis of Pediatric Patients Presenting to a Reference Child Hospital with Poisoning Complaint. Behcet Uz Pediatrics Journal 2020;10:299-305.

13. Ozdemir R, Bayrakci B, Tekşam O, Yalçin B, Kale G. Thirtythree-year experience on childhood poisoning. Turk $\mathrm{J}$ Pediatr 2012;54:251-9.
14. Aktepe E, Kocaman O, Ișık A, Eroğlu F. Evaluation of Child and Adolescent Psychiatry Consultation Services in a University Hospital. TAF Preventive Medicine Bulletin 2013;12: 539-44.

15. Ersoy Şimşek EG, Eyüboğlu M, Eyüboğlu D. Evaluation of Child and Adolescent Psychiatry Consultation Services in a University Hospital. Osmangazi Med J 2019;41:248-56.

16. Gökçen C, Çelik YY. The Evaluation Of Child And Adolescent Psychiatry Consultations from other Inpatient Clinics in a Training Hospital. Sakarya Med J 2011;1:140-4.

17. Emiroglu N, Aras S, Yalin S, Dogan Ö, Akay A. Evaluation of Child and Adolescent Psychiatry Consultation Services in a University Hospital for inpatients. Anatolian Journal of Psychiatry 2009;10:217-25.

18. Göker Z, Güney E, Dinç G, Üneri Ö. Evaluation of Child and Adolescent Psychiatry Consultation Services in a University Hospital. Turkish J Pediatr Dis 2014;8:17-24 